\title{
Finnish Official Development Aid for Sexual and Reproductive Health and Rights in Sub-Saharan Africa
}

\author{
RIIKKA SHEMEIKKA, Dr.Soc.Sc., M.Sc., Post-Doctoral Researcher \\ Population Research Unit, Department of Social Research / Sociology \\ University of Helsinki
}

\section{Abstract}

Finland is one of the donor countries that is most supportive in family planning (FP), Sexual and Reproductive Health and Rights (SRHR) and gender issues. This study examines Finnish ODA for FP and SRHR: its decision-making structure, other stakeholders and funding levels. Data consists of documents from the Ministry for Foreign Affairs (MFA) and interviews conducted at the MFA and with other experts. While Parliament decides on the overall level of ODA funding, the Minister for Foreign Trade and Development has considerable autonomy. Other stakeholders such as the All-Party Parliamentary Group on Population and Development and the Family Federation of Finland (Väestöliitto) engage in advocacy work and have influenced development policy. Although the Development Policy 2007 mentions the importance of health and SRHR issues and HIVIAIDS is a cross-cutting issue, interviewees stated that the importance of health and SRHR in ODA has declined and that the implementation of cross-cutting issues is challenging. Multilateral funding for UNFPA, UNAIDS and GFATM, and thus the proportion of SRHR funding within the health sector, is however currently rising. Funding for population-related activities has increased and represented 4.8\% of Finland's total ODA in 2009. Almost all of this funding is directed towards basic reproductive health and HIV/AIDS issues and the majority is directed through multilateral channels (78\% in 2009), mainly UNFPA and UNAIDS. $I P P F$, Ipas and Marie Stopes International also receive support.

Keywords: Official Development Aid, ODA, Sexual and Reproductive Health and Rights, SRHR, Family Planning, HIV, AIDS, ODA for Population Activities, ODA for SRHR, Finland, sub-Saharan Africa, Ministry for Foreign Affairs, NGO, INGO, UNFPA, UNAIDS, GFATM, IPPF, decision-making

\section{Introduction}

Improvements in global sexual and reproductive health and rights (SRHR) are important from many viewpoints. As well as improving the wellbeing of individuals and families, such improvements also support sustainable development: eliminating the unmet need for family planning, for example, would not only slow global population growth but also help in mitigating the causes of climate change change (O'Neill, MacKellar 
\& Lutz 2001). Enhancing SRHR in global terms also helps work aimed at achieving the Millennium Development Goals (MDG), especially improvements in maternal and child health, both of which were subjects of special attention at the recent MDG Summit in New York in September 2010 (Ki-Moon 2010).

Among OECD countries, Finland is known as one of the countries in which the proportion of official development aid (ODA) directed to SRHR has reached the $4 \%$ target level set by the International Conference on Population and Development (ICPD), and also as one of the most important donors to UNFPA (Makura et al. 2005). Finland is considered to be one of the 'like-minded' donors, i.e. part of a group of European donor countries who are striving to be most supportive in family planning, SRHR and gender issues. These countries include the Nordic countries, The Netherlands, the UK and Germany. During the administration of George W. Bush, the provision of support by like-minded countries to many organizations working in the fields of population issues and SRHR, including the United Nations Population Fund (UNFPA), was particularly essential. Research into decision-making structures and policies in the like-minded countries is useful both for sharing the successful practices with other countries, and in improving further the efficiency of ODA directed to family planning and SRHRrelated activities in those places.

This paper is based on the results of a background study concerning Finnish ODA for family planning (FP) and SRHR in sub-Saharan Africa. It is part of a wider international research undertaking by the William and Flora Hewlett Foundation. In this research, one of the aims is to identify, document and propose improvements in the way that the like-minded donors provide development cooperation funds for family planning and reproductive health. Similar background studies have been carried out or are currently being prepared in Denmark, Sweden, Norway, Netherlands, UK and Germany. On the basis of the results of these country-based reports, a summary report will be prepared by the Hewlett Foundation in early 2011.

This paper studies ODA for FP and SRHR that is directed to sub-Saharan Africa. A short presentation of earlier research on the topic is followed by a presentation of the aims, data and methods used in the study. The decision-making structures employed in the ODA sector are examined, as well as the role of other actors in the field of global SRHR issues. The latest information on ODA levels is then presented with a specific focus on ODA directed to population-related and SRHR activities. Based on the views expressed by interviewees, opportunities for improvements in ODA for SRHR are briefly discussed. The conclusions of the study are then presented. A list of the people interviewed is provided. 


\section{Earlier research on ODA for population activities and SRHR in Finland}

The most important research related to the topic handled in this article is a report on ODA for population-related activities by Marketta Ritamies (1989). In this study, which was commissioned by the Department of Development Policy of the Ministry for Foreign Affairs (FINNIDA at that time), Ritamies thoroughly mapped Finnish ODA for population-related activities, assessed the resources available for these activities, and made recommendations regarding future needs for development aid being directed to tackle global demographic challenges. In her recommendations, Ritamies said that, among others, support should be given to actions which restrict over-rapid population growth to avoid the resulting economic, social and environmental problems, and that support can also be given to family planning in order to enhance the wellbeing of individuals and families, especially by reducing the negative effects of abortions and maternal and child mortality. She recommended that the ODA directed to population activities should be increased to $5 \%$ of total ODA, the level prevailing in other Nordic countries, and that a family planning component should be included in all basic health projects. She also said that the proportion of bilateral ODA should be lower than in ODA in general at around $20-30 \%$, that the level of multilateral ODA for population activities should be increased, and that increased funding should be provided for both UNFPA and UNICEF in particular. Her recommendations included an increase in funding directed through international non-governmental organizations (NGOs), with funding (including core funding) for the International Planned Parenthood Foundation (IPPF) and the Population Council being mentioned.

According to the recommendations made by Ritamies $(1989,109-111)$, bilateral ODA for population activities should be directed to the least developed countries in which population growth is strongest, with priority being given to countries in Africa. She said that Finnish bilateral ODA for population activities should be directed towards the following areas: 1 ) the building of family planning service networks (the prevention of HIV/AIDS was also mentioned in this connection); 2) the collection of basic demographic information (including population censuses and vital registration); and 3) support for demographic research in Finland and in developing countries.

Other recommendations included, for example, recommendations regarding research cooperation between Finnish institutions, including family planning, HIV education and health education NGO ODA, and a recommendation that ODA for population activities should in the main be donations not tied to specific Finnish personal or material resources (Ritamies 1989).

ODA for population activities has also been studied by Hatunen in her master's thesis (1976) and also by Ollila (1994). In her paper, Ollila reviewed the state of population ODA in the early 1990s and discussed its possible future development (Ollila 1994). Finnish ODA for SRHR has been assessed in other than academic studies, such as in 
evaluations made for the MFA (one example is an evaluation of ODA for the health sector by Kolehmainen-Aitken et al. 2005). Internationally, published research on ODA for SRHR mostly consists of ODA evaluations (e.g. Geisler et al. 2004). To a lesser extent, research into the topic can also be found in an academic context, for example as part of a doctoral dissertation on ODA management (Janssen 2009).

Academic research on ODA in Finland mostly focuses on topics other than populationrelated activities, including the impacts of development interventions in different locations, for example in Tanzania, Vietnam and Nepal, and the focus of such research is often the forestry sector (see e.g. Gould and Siitonen 2007; Koponen 2004). Some of the many other ODA-related topics studied by scholars in the field of development studies in Finland include: learning processes in NGOs engaged in development cooperation (Konttinen 2007); politics and partnership agreements (Laakso 2007); EU development aid and development policy (e.g. Siitonen 2007); development aid and conflict prevention (Hossain, Siitonen and Sharma 2006); and aid modalities and governance (Gould 2006).

\section{Aims, data and methods}

The general aims of the paper are to examine the current decision-making structure concerning ODA for Family Planning (FP) and Sexual and Reproductive Health and Rights (SRHR) in Finland and to assess the possibilities for collecting information on the level of funding going to FP and SRHR in general, with specific attention being given to the level of funding directed to sub-Saharan Africa in these two fields.

The detailed aims of the paper are 1) to study the respective roles of the Finnish Parliament, the Finnish Government, the Minister for Foreign Trade and Development, civil servants at the Ministry for Foreign Affairs (MFA) and its Department of Development Policy, and Finnish embassies in sub-Saharan Africa in the making of decisions that concern ODA, 2) to identity other relevant actors who influence the making of decisions on ODA for FP and SRHR and to assess the roles they play, 3) to discuss with different stakeholders the opportunities that may exist for improving Finnish ODA for FP and SRHR, 4) to assess the kinds of information available about levels of ODA directed to FP and SRHR in general and specifically in sub-Saharan Africa, and 5) to establish the levels of ODA being provided in the FP and SRHR fields through different channels: e.g. multilateral ODA through different organizations, sector support for the health sector, ODA for bilateral programs and projects, support for non-governmental organizations (NGOs) and international non-governmental organization (INGOs) and also, if possible, to arrive at a more precise division of this funding between different branches of FP and SRHR. In addition, as a major part of Finnish funding in this sector passes through UNFPA, one of the aims of the study was to collect views on the performance of this organization. 
The data consists of published policies, strategies, guidelines and reports issued by the MFA, and the results of interviews conducted with civil servants in the MFA, experts and other stakeholders in the sector. Documents were selected by examining publications listed on both the Finnish and English MFA websites, and by requesting relevant papers during interviews. Documents were downloaded from the MFA website or obtained from contact persons at the MFA. For ODA data, both published reports and extra data provided by civil servants working in the MFA were employed. Interviews were conducted at the MFA, at the Parliament, at the University of Helsinki, at the National Institute of Health and Welfare, and at relevant NGOs. Interviewees were selected using existing knowledge of the sector and by requesting advice from experts about suitable individuals. The semi-structured questionnaires used in interviews were based on the suggestions based on similar studies that have been carried out in other countries, modified to suit the Finnish context and the institutional background of the people being interviewed. All interviews were recorded, and the analysis is based both on these recordings and notes made during the interviews.

\section{Results}

\section{Decision-making at political/strategic level}

At the highest political level, the Government Programme and the state budget represent the framework for development cooperation in Finland.

The Government Programme, which is agreed as a result of negotiations between the political parties represented in Government, provides general guidelines for development cooperation. The Government Programme is submitted to Parliament in a form of Government statement.

The administration headed by Prime Minister Mari Kiviniemi which took office in June 2010 is continuing implementation of the Government Programme declared by the second administration government that was headed by Matti Vanhanen (Government Statement 2010; Prime Minister's Office 2007). According to this Government Programme, the most important objective in international development policy is attainment of the UN Millennium Development Goals (MDGs). Achievement of the UN target for the level of Official Development Aid (ODA) - $0.7 \%$ of gross national income (GNI) - will be advanced. The Government Programme emphasizes the importance of innovative funding mechanisms and debt-relief programs, efficiency, effectiveness and recipient countries' ownership of development cooperation, and the division of labor between donors. The role of environmental and climate issues, crisis prevention and support for peace processes will be emphasized in Finland's development policy. Trade policy and the special needs of developing countries are acknowledged, as well as Finland's role in promoting human rights world-wide. Health-related topics are not mentioned in the Government Programme, even though they may be viewed as be- 
ing included in the MDGs. Issuing a human-rights policy report was included in the Government Programme's targets, and in this report, which was published in 2009, the rights of women and girls, including sexual and reproductive health and rights, were defined as one of the priorities (MFA 2009a). Finland's next parliamentary elections will take place in April 2011, and the new administration, once formed, will accept a new Government Programme.

In parliament, MPs possibilities for influencing Finnish ODA are limited. Parliament does however have budgetary power. Each spring, it discusses the budget framework based on approved spending limits. Based on this framework, ministries draft their own budgets, and negotiate with the Ministry of Finance during this process. The Government then submits its budget proposal in the autumn, and this proposal is discussed in a plenary session, handled by committees, and finally approved by parliament. In the state budget, parliament approves the amount of ODA. In the budget proposal, the planned division of ODA between, for example, multilateral, country-based and region-based development cooperation is presented, together with funding for different UN organizations including UNFPA. The principles underlying Finnish development policy, including issues receiving specific emphasis, are presented. The latest budget proposal made to Parliament (MF 2010) states that the most important aim of Finland's development policy is the eradication of poverty and the promotion of sustainable development in accordance with the MDGs. In development policy, the emphasis is placed on environmental and climate issues, crisis prevention and support for peace processes, as well as the utilization of Finnish expertise and experience. Cross-cutting issues, i.e. promoting the rights and status of women and girls, promoting gender and social equality, promoting the rights of groups that are easily excluded, and combating HIV/AIDS, are also mentioned.

According to the interviews, however, discussion of these details during the budget discussions in parliament is rare. Experts said that there have been very few plenary session discussions about ODA in parliament, as ODA-related issues are mostly handled in the parliament's Foreign Affairs Committee. This committee monitors development policy and issues statements relating to it, and also holds hearings attended by experts on ODA-related issues. However, one of the interviewed persons who was invited to attend one of these hearings in an expert capacity noted that the decisions discussed had already appeared in printed form before the session took place.

There will most probably be pressure in parliament to cut funding levels in future. Dr Paavo Väyrynen, the current Minister for Foreign Trade and Development, has successfully defended ODA funding and maintained it at a high level even during the economic downturn. In what is a significant exception to international trends, Finnish ODA has grown steadily in recent years and the budget for 2011 includes yet another increase. The precise definition of ODA is also an important issue, for example climate change funding was made a component of ODA despite opposition from NGOs and some other actors. 


\section{Decision-making at ministerial level}

In practice, the Minister for Foreign Trade and Development, the Ministry for Foreign Affairs (MFA) and its Department of Development Policy have a lot of independent decision-making power regarding Finnish ODA. This is in line with the system employed by other ministers and government ministries in Finland. MFA prepares the ODA budget for the Government's budget proposal which is subsequently approved by the Parliament. MFA also prepares the Development Policy Programme which becomes a Government Decision-in-Principle, prepares other policies, strategies and guidelines guiding Finnish development policy, and makes ODA-related funding decisions. Different ministers exhibit different levels of activity and involvement regarding such decisions, and the balance of power between the Minister and civil servants therefore varies over time.

\section{Development Policy Programme 2007 and the position of health and SRHR}

The most important policy document guiding Finnish development cooperation is the Development Policy Programme (MFA 2007). Other operative policies, action plans and codes of practice related to the scope of this report include, for example, the Government report to Parliament on the human rights of Finland (MFA 2009a), The Cross-cutting Themes in Finnish Development Cooperation: Guidelines (MFA 2009b), Finnish Development Policy Guidelines for the Health Sector (MFA 2007b), HIV/Aids as a development issue - Foreign Ministry Policy (MFA 2004), Africa in Finnish development policy - development policy framework programme (MFA 2009c), General Budget Support and Sector Budget Support in Finland's ProgrammeBased Development Cooperation (MFA 2010), Multilateral Cooperation in Finland's Development Policy (MFA 2008a), and Policy on non-governmental organizations (MFA 2006, new version to be published in 2010). (More policies, guidelines and other publications are presented in the appendix).

The Development Policy Programme 2007 that is currently in effect was designed and approved after the current Minister was appointed, and replaced the Development Policy Programme of 2004. According to interviews, the process of formulating the current programme differed from that used to produce the previous one. Preparations for the new Development Policy Programme were already ongoing when the new Minister took up his post. The Minister had strong opinions and assumed an active role in formulating the draft for development policy. According to interviews, motivated by, among other things, the weak position of the social dimension in the draft, strong representations were made by NGOs, the All-Party Parliamentary Group on Population and Development and some other actors, all of whom requested that the drafting of development policy be opened up to wider discussion,. Comments on the draft were requested from a limited number of NGOs, but the very-tight timetable made commenting difficult. Meetings to consider researchers' comments were not organized. On the positive side, following an initiative by the All-Party Parliamentary Group on Population and Development 
and development NGOs, a discussion of ODA actually did take place in parliament, a very unusual event. Views regarding the results achieved by these comments varied among the experts interviewed. Some considered that remarkable progress was made in connection with the position of health and SRHR (sexual and reproductive health and rights) issues in development policy, others did not see much change.

According to interviews, preparations for the previous Development Policy Programme (2004) were very different. The process was much longer, began with country-based analyses of the partner countries, and discussions regarding the programme during the preparation phase were much wider. Also, the Development Policy Committee had been more involved in preparing the 2004 programme than was the case in the current one.

According to the Development Policy Programme 2007, the main goal of the development policy is to eradicate poverty in accordance with the UN Millennium Development Goals (MDGs) (MFA 2007). This is seen as possible only if the progress made in developing countries is 1) economically, 2) socially and 3) ecologically sustainable. In the social dimension, the importance of good education (in particularly the education of girls and women) is recognized, as well as promoting public health, the positive effects of migration, democratic decision making and good governance. Respect for human rights is seen as a condition for successful development. In promoting health, special attention must be given to combating communicable diseases, to sexual and reproductive health and rights, to improving maternity and child welfare clinics, and to developing health services and primary health care. Access to clean water and food is also mentioned. It is stated that three cross-cutting themes should be supported throughout all Finnish development policy, i.e. 1) promoting the rights and status of women and girls, 2) promotion the rights of groups that are easily excluded, and 3) combating HIV/AIDS. Coordination between donors is emphasized, as well as the link between security, development and human rights. Finland recognizes the role of the United Nations as the most important actor in international development policy and supports a strengthening of the global role of the European Union. The European Consensus on development is recognized. The guiding principles for development policy are said to be coherence, complementarity and effectiveness. Finland is committed to reach development cooperation appropriations of $0.51 \%$ of GNI by 2010 and $0.7 \%$ by 2015 . The Development Policy Programme 2007 also states that Finland will continue its bilateral programme-based cooperation in the forestry, agriculture, water, environment, energy, education and training, health, and regional and rural development sectors, and that emphasis will be placed on sustainable, especially ecologically sustainable development.

According to official development policy, Finland promotes economically, socially and ecologically sustainable development, and places particular emphasis on the importance of issues relating to climate and environment. Although the three dimensions 
of sustainability are all mentioned in current development policy, many interviewees expressed the opinion that that in promoting sustainable development, the social dimension has received less attention than the economic and ecological dimensions, and that the environmental dimension has received particular emphasis in both Finnish development policy and ODA.

A corresponding view expressed by one interviewed expert who has followed Finnish development policy for a long time was the opinion that population and health issues have never held a very strong position in Finnish development policy. During the early 2000s, such issues received slightly more attention because politics at international level was being directed towards, among others, maternal health issues and HIV. Some of the experts interviewed expressed the view that the incumbent Minister considers demographic issues important because of their connection with population growth and thus to sustainable development. This could be one factor that is influencing increased funding for UNFPA.

Insights provided by the interviewed experts indicate that the line followed in development policy is influenced by both the incumbent Minister's personal views and global trends and themes. During the current administration, climate change and the economic downturn have been topical subjects, during the period of the former administration, it was globalization and HIV/AIDS. Development policy programmes are reformulated as and when necessary. If a new Minister is appointed after the 2011 parliamentary elections, it is quite probable that a new Development Policy Programme will result. The phase when new development policy is being created is a good time to exert influence - MFA staff usually produce the draft and then, through advisors, experts can have their say. Some MPs and NGOs whose aim is to improve policy in the field of FP/SRHR are already making preparations for discussions relating to a future Development Policy Programme.

\section{Implementation of development policy in the funding of health and SRHR in Finnish ODA}

Both health and SRHR are mentioned in development policy, as well as bilateral support for the health sector. At policy level, the position taken regarding family planning, safe abortions and handling gender-based violence has been stable. Health and SRHR are not, however, considered to be priority areas and the proportion of support provided for the health sector has diminished. Bilateral health projects have ended without new projects being initiated. On the other hand, multilateral cooperation such as funding for UNFPA has increased. The only African country in which Finland provides traditional bilateral health sector ODA is Mozambique, and even this is being phased out. There is also a health sector program in Nicaragua, and Afganistan receives bilateral health ODA. Funds for health sector and reproductive health services are also being provided, for example, through the Institutional Cooperation Instrument (ICI), through humanitarian aid, and to some extent through concessional credits. In addition, NGOs and INGOs work on 
health sector and on reproductive health. Activities connected with safe abortions are mostly funded through Ipas and to a certain extent through the International Planned Parenthood Federation (IPPF). Funding for combating HIV is only done through multilateral channels such as UNAIDS and the Global Fund, and through NGOs. Research funding for SRHR is mainly provided through the Academy of Finland. Because of the increased funding provided to UNFPA (among others), the proportion of funding allocated to reproductive health within the health sector has been increasing.

According to the recently-accepted policy paper on general budget support and sector budget support (MFA2010a), Finland will shift the focus of budget support from general budget support (GBS) to sector budget support, and the level of GBS will be limited to a maximum of $25 \%$ of the support delivered to any individual country. In this paper it is also stated that to promote economically and ecologically sustainable development, programme-based sector support will be reinforced, particularly in the agriculture, forestry, water, information society, energy and environmental sectors. In addition, socially-sustainable development will be promoted in education and health sectors.

According to interviews carried out at the MFA, the emphasis is moving from sector support towards bilateral support. According to Development Policy Programme 2007, project cooperation continues particularly in countries where management systems are not conducive to programme-based cooperation. Project cooperation is also seen as an opportunity to utilize Finnish know-how and expertise (MFA 2007, 28). In interviews with experts, worries were expressed that this emphasis on Finnish know-how and expertise is leading to supply-led ODA on the basis of specific Finnish interests and especially the interests of Finnish commercial concerns. On the other hand, one of the experts interviewed was concerned that Finnish ODA experts in the health and SRHR sectors are leaving Finland and joining international organizations because demand for their expertise is declining. This will lead to a loss of expertise in this field, which will then be a problem when the emphasis of national development policy changes again. Also, the emphasis on Finnish know-how and expertise could conflict with recipient countries' ownership of ODA.

Together with other like-minded countries, Finland supports the World Bank Gender Action Plan, which means that a considerable amount of funding is going to be directed to implementing gender policies. A World Development Report on gender will be published in 2012, and preparations for this have started. The Council of the European Union recently approved a gender and development action plan (including SRHR) which will have a specific monitoring system.

\section{Some strategies and guidelines relevant to SRHR}

While forming strategies and guidelines, the initiative is sometimes provided by technical staff, but mostly comes from the needs of development policy. For example, if there are a lot of new forest projects, a forest strategy will be needed. Gender 
strategy was only valid until 2007 when the new development policy began, but it has been decided that a new gender policy was unnecessary. Even though such a policy is no longer valid, it is to some extent still implemented, but doing this requires a lot of work from advisors. At embassy level, gender aspects are not always included in programs. Whether this happens also depends on the partner country's priorities. On the other hand, gender has long considered to be a cross-cutting issue and is probably easier to include in projects than some other issues. Also, there is a kind of collective appreciation for gender issues in Finland.

Cross-cutting issues require special attention to avoid them being neglected. Sectors that are currently the subject of emphasis, for example forestry, have not traditionally been the kind of sector into which gender is easily fitted. An evaluation of cross-cutting themes in Finnish ODA showed that there were difficulties in its implementation (MFA 2008b). A short guideline was therefore prepared (MFA 2009b).

The MFA's HIV strategy is relatively old but still valid (MFA 2004). A brochure on sexual and reproductive health and rights was published recently (MFA 2010b). There are health sector guidelines (MFA 2007b) and in interviews, experts from outside MFA expressed a need for a separate SRHR strategy.

\section{Other topics related to decision-making at ministerial level}

According to the interviews with experts, the balance of power between the Minister and civil servants working in the Department of Development Policy at the Ministry for Foreign Affairs depends to a significant extent on the personal preferences of the Minister currently holding the office. Most of the time, civil servants have a measure of independence, but the current incumbent has taken a more active role. In development policy, this means that the line currently being followed by Finland is not fully dictated by international development politics but has its own emphases. When civil servants have more independence, Finland's national policy is usually more closely aligned with international development policies, which is in turn influenced, among others, by the EU, the World Bank and the UN.

Among civil servants in the MFA, the most influential are the Under-Secretary of State for Development Cooperation and Development Policy and the directors of departments and units, but counselors also have an influence on ODA funding. All ODA projects are approved by a quality group which scrutinizes proposals for programs and projects. This quality group consists of people from different MFA units. While some ambassadors also hold influential positions, the ODA funding sector includes very limited funds to be used by embassies. Compared to other like-minded countries, much of the decision-making on funding is happening at headquarters level. In this respect, desk-officers at geographical units may be viewed as being in a kind of gatekeeper role. According to one expert interviewee, this can be problematic: it would be better to move decision-making to country level where the expertise and knowledge 
of local needs exists. Also, the fact that other donor countries have much higher levels of funds for which uses can be decided at embassy level makes life complicated for officials working in Finnish embassies who seek to cooperate with them - decisions regarding ODA funding are mostly made in Helsinki.

In decision-making, cooperation within MFA is also important. Meetings such as summer gatherings and sectoral meetings for civil servants are important. Some advisors to the MFA work closely together, but not all of them. If more time and opportunities were available, closer cooperation could be advantageous.

\section{Other actors in the field of ODA for SRHR}

Several organizations in Finland are relevant actors either in the field of SRHR-related ODA or ODA in general.

The All-Party Parliamentary Group on Population and Development (APPG) is a forum for Finnish MPs who are interested in promoting global SRHR issues. The group has members from almost all political parties, with the most active being the Greens, the Left Alliance and the Social Democratic Party . Ms. Minna Sirnö chairs this group, which cooperates actively with other advocacy groups in this sector. The group tables parliamentary questions, issues statements, organizes meetings with suitable development stakeholders at national, European and international level, organizes study trips to developing countries for MPs, organizes seminars, distributes information on SRHR to MPs and carries out other advocacy work such as providing reminders of what is actually been done within ODA to avoid the inclusion of costs associated with, for example, measures to mitigate the effects of climate change or the accommodation of refugees ("The target level should be $0.7 \%$ plus climate change"). This group was active also during the process of formulating the Development Policy Programme 2007. The APPG works with Väestöliitto, the Family Federation of Finland, which provides both advisory and secretariat functions for the Group.

In development policy and cooperation, the Family Federation of Finland (Väestöliitto, FFF) is the only NGO in Finland whose focus is on global population and SRHR issues. The federation's Global Development Unit is the country's most-important advocacy unit in the field of global SRHR issues and has good connections to other NGOs, to civil servants at MFA, and to MPs and the other high-level political figures. The federation has, for example, advocated to the Minister that SRHR should become a cross-cutting issue and component in all ODA projects, and took the initiative in preserving ODA for maternal clinics in Afghanistan. The All-Party Parliamentary Group on Population and Development was established following an initiative by FFF. FFF has an advisory role and provides the Secretariat for both APPG and The Friday Group (see next paragraph). The FFF also lobbies and has provided expertise on demand for the MFA in connection with SRHR-related topics. In addition to its advocacy work, FFF has its own ODA projects in Malawi and Nepal and runs the Population Research Institute. 
Although studies of SRHR issues in Africa are not currently being conducted by this organization, research on related topics has been carried out elsewhere.

The Friday Group is a think-tank for MPs, NGOs operating in the development sector, and civil servants working in different ministries. It provides opportunities for information sharing and the discussion of development issues, including SRHR. The Friday Group was active during the comment period for the Development Policy Programme 2007.

Funded partly by MFA and having almost 280 member NGOs, the Service Center for Development Cooperation (KEPA) is a service base for Finnish NGOs interested in development work and global issues. It works to improve the quality of ODA and increase the development aid budget (e.g. KEPA 2010). Advocacy work is directed towards MPs and the provision of advice and training for NGOs. The center is active in the field of development policy and cooperates, among others, with the All-Party Parliamentary Group on Population and Development, The Friday Group and FFF.

The International Affairs Unit, National Institute for Health and Welfare (THL) is part of a government organization closely associated with the Ministry of Health and Social Affairs. Since 2003, unit experts have cooperated with MFA by executing, sometimes at very short notice, small assignments such as participation in meetings to represent Finland, assessing funding applications from NGOs, reviewing research grant applications, etc.

The members of Development Policy Committee represent parliament and civil society, including, among others, representatives from different political parties, academic researchers, and NGOs, as well as expert members recruited from different ministries. This committee provides advice and thus 1) steers Finnish development policy work, 2) evaluates the quality and effectiveness of development policy, and 3) monitors levels of public funding for development aid. The committee produces an annual report on the state of Finland's development policy, the latest issue was published in June 2010 (Development Policy Committee 2010). The Development Policy Committee holds regular meetings. Currently, the number of members representing NGOs has fallen and there are new members from commercial concerns, and vice-members have been dispensed with, all of which makes the holding of decision-powered meetings more difficult. The Development Policy Committee has good connections with the Foreign Affairs Committee in Parliament. During interviews with representatives from other actors in the sector, the Development Policy Committee was not usually reported as being a very active actor or as a significant cooperation partner.

In addition, some NGOs have included some aspects of SRHR in their work. Many of these actively cooperate with each other and are members of The Friday Group. These NGOs initiate and influence policy-making by, among other methods, commenting on Ministry papers during the preparation phase, and then again by commenting on 
proposals being considered by Parliament. MFA has made partnership agreements with some of these NGOs (including the Finnish Red Cross and World Vision Finland), which ensures that funding for projects is more stable. Partner NGOs also cooperate closely with MFA, for example their comments are requested and they participate in meetings during preparations for UN conferences. One problem for NGOs in working in the ODA sector is the need to raise a large proportion of their own funding. Consultancy firms do not have to do this. This situation could be changed by making additional exceptions as such exceptions for NGOs working with disabilities already exist. NGOs' expertise could also be utilized to a greater extent, for example Väestöliitto (the Family Federation of Finland) could provide training on the implementation of cross-cutting issues and related subjects.

\section{Information, data, reporting}

\section{Data on ODA}

The latest year for which data on Finnish ODA is available is 2009. OECD/DAC reporting took place in mid-July 2010. MFA reports to Parliament about development cooperation on an annual basis and these reports include information on ODA. Information on ODA is also available in an $\mathrm{OECD} / \mathrm{DAC}$ database.

The total value of development cooperation disbursements was EUR 923.6 million, which is $0.54 \%$ of Finland's gross national income (GNI) (MFA 2010c). The increase from $0.44 \%$ of GNI in 2008 was partly due to an increase in development cooperation and partly to the reduction in GNI in 2009 that resulted from the global economic downturn.

Development cooperation disbursements are divided into two categories: actual development cooperation (EUR 671.3 million) and other public development items (EUR 252.3 million). Among other items, the latter includes a share of the EU development cooperation budget, administrative expenses, and costs associated with accepting refugees.

The largest items of actual development cooperation disbursements are country-specific and region-specific disbursements (EUR 223.7 million, 33\%), multilateral development cooperation (EUR 198.7 million, 30\%), support for NGO development cooperation (EUR 86.1 million, 13\%) and humanitarian aid (EUR 73 million, 11\%).

\section{Multilateral development aid for SRHR}

UNFPA is one of the main recipients of Finnish multilateral ODA. The funding provided increased from EUR 12.45 million to EUR 21.0 million between 2000 and 2009 (MFA 2010a), with the increase being more rapid than that among other UN organizations in recent years. Published plans indicate that the increase will continue in the future. Multilateral support for combating HIV/AIDS through UNAIDS and the Global Fund to Fight AIDS, TB and Malaria (GFATM) has also increased in recent years. Finland is 
a significant long-term supporter Table 1 . General grants to multilateral organizations with SRHR activities in 2009 (EUR million).

Table 1. General grants to multilateral organizations with SRHR activities in 2009 (EUR million).

\begin{tabular}{lc}
\hline Channel & Disbursements, EUR million \\
\hline UNFPA & 21.0 \\
UNDP & 19 \\
UNICEF & 16.6 \\
UNAIDS & 9.0 \\
UNCHR & 7.0 \\
GFATM & 3.5 \\
WHO & 1.45 \\
UN Foundation & 1.26 \\
UNIFEM & 0.9 \\
\hline
\end{tabular}

Data: MFA 2010c, 2010d.

\section{Bilateral and NGO ODA}

Bilateral ODA is reported in an annual development cooperation report (MFA 2010c) and in Kehitysyhteistyön rahoituskohteet (Development Cooperation Funding Targets, only available in Finnish) (MFA 2009g).

The share of total bilateral development cooperation disbursements going to sub-Saharan Africa was EUR 157.3 million (whole Africa: EUR 179.7 million) (MFA2010c). For country-specific and region-specific disbursements, Finland's largest partner countries in Africa are Tanzania (EUR 31.6 million), Mozambique (EUR 26.6 million), Zambia (EUR 15.7 million), Ethiopia (EUR 11.5 million), South Africa (EUR 7.9 million), Kenya (EUR 5.8 million) and Namibia (EUR 2.0 million).

Detailed reports on program-based cooperation in 2009 is available for three categories: general budget support (total EUR 27.04 million), sector budget support (EUR 15.84 million) and baskets or funds for joint-financed programs (EUR 45.84 million) (MFA 2010e). These three categories totaled EUR 88.72 million, out of which EUR 62.28 million was directed to sub-Saharan Africa (Table 2). Until 2002, Mozambique's health sector received sector budget support. Subsequently, support for Mozambique's health sector has consisted of baskets or funds for joint-financed program support. In 2009, the Mozambique health sector received support totaling EUR 6 million. Outside Africa, Nicaragua received similar financing totaling EUR 1.4 million. In 2009, sector budget support was provided for the rural development, administration and forestry sectors. In addition to the health sector, support from baskets or funds for joint financed programs was provided to the following sectors in Africa: administration, economy, 
education, forestry, water, agriculture and the environment. Corresponding data on program-based bilateral projects is not available for 2009 , but data reporting methods are being developed and this data will probably be available in subsequent years.

Table 2. General budget support (GBS), sector budget support (SBS) and baskets or funds for joint financed programs (BF) for sub-Saharan African countries in 2009, (EUR million).

\begin{tabular}{lrrcrr}
\hline Country & GBS & SBS & $\begin{array}{c}\text { BF health } \\
\text { sector }\end{array}$ & $\begin{array}{c}\text { BF other } \\
\text { sectors }\end{array}$ & Total \\
\hline Ethiopia & 0 & 0 & 0 & 3.51 & 3.51 \\
Kenya & 0 & 0 & 0 & 1.88 & 1.88 \\
Mozambique & 7.04 & 4.57 & 6 & 5 & 22.61 \\
Zambia & 5 & 0 & 0 & 2.73 & 7.73 \\
Tanzania & 15 & 1.5 & 0 & 7.05 & 23.55 \\
Sudan & 0 & 0 & 0 & 3 & 3 \\
\hline Total & $\mathbf{2 7 . 0 4}$ & $\mathbf{6 . 0 7}$ & $\mathbf{6}$ & $\mathbf{2 3 . 1 7}$ & $\mathbf{6 2 . 2 8}$ \\
\hline
\end{tabular}

Data: MFA 2010e.

Embassies have some funds for use in local cooperation projects, but they are clearly smaller than in like-minded countries in general, totaling just EUR 10-20 million on an annual basis. Most ODA decisions are made at headquarters, i.e. at the MFA in Helsinki.

Support for NGO development cooperation totaled EUR 86.1 million in 2009, which represents $13 \%$ of actual development cooperation disbursements. Details of funded NGO projects are reported annually in Kansalaisjärjestöhankkeet (NGO projects, only available in Finnish) (MFA 2009i).

\section{Development cooperation directed at population activities, including SRHR}

Possibilities for tracking ODA flows to family planning and SRHR are limited. One possibility is the use of OECD/DAC CRS codes, but the information available in this form is limited. Other alternatives would be by carrying out keyword searches of project descriptions, but such results would be less than fully reliable. DAC codes ensures comparability between countries. There are forms of support such as General Budget Support and multilateral ODA on which additional information is simply not available.

To monitor progress in implementation of the Programme of Action adopted at the International Conference on Population and Development (ICPD), the Resource Flows Project (also called here the UNFPA/NIDI survey) tracks the flow of financial resources from primary donors to population activities. These activities include the following categories: 1) Family Planning Services, 2) Basic reproductive / maternal health services, 3) Sexually-transmitted diseases and HIV/AIDS activities, and 4) Basic research, data and population and development policy analysis. 
This UNFPA/NIDI survey utilizes OECD/DAC CRS codes. DAC 5 code 130 (Population policies / programmes and reproductive health) includes the following CRS codes: 13010 (Population policy and administrative management), 13020 (Reproductive health care), 13030 (Family planning), 13040 (STD control including HIV/AIDS), 13081 (Personnel development for population and reproductive health). Together with CRS code 16064 (Social mitigation of HIV/AIDS), these CRS codes refer directly to activities in the field of population and SRHR.

In addition, there are other CRS codes in the UNFPA/NIDI survey which are judged as partly referring to population activities. For example, resources devoted to CRS 11220 (Primary education) were calculated as having a 10\% contribution to population activities and resources devoted to CRS 12240 (Basic nutrition) were calculated as having a $75 \%$ contribution.

Similarly, estimates of the proportion of funds directed to intermediate organizations (i.e. organizations which channel resources for population activities from primary donors such as UN agencies, development banks, NGOs) used for population activities were also calculated. For example, all funds directed to UNFPA are calculated as going to population activities, while $9 \%$ of funds directed to UNIFEM are calculated as being used in this way. (Estimated proportions for some organizations (i.e. the proportion going to population activities) include: UNFPA $100 \%$, UNAIDS 100\%, UNIFEM 9\%, UNICEF $8 \%$, UNDP $8 \%$, WHO 9\%, UN Foundation 4\%, GFATM 56\%).

According to a 2008 report, Finland's population-related assistance totaled EUR 41.6 million, i.e. USD 61.1 million (the rate of exchange used in the survey was EUR $1=$ USD 1.47080) (MFA 2009h). Of this, project or program expenditures totaled USD 19.2 million, $73 \%$ of which was directed towards basic reproductive health services, $25 \%$ towards STD and HIV/AIDS activities, $2 \%$ towards basic research, data and population and development policy analysis, and $0 \%$ to family planning services.

In 2008, division of total population assistance (USD 61.1 million) by distribution channel shows that $77 \%$ (USD 47.1 million) was directed through multilateral channels, 20\% (USD 12.5 million) through NGOs, and 3\% (USD 1.6 million) was directed directly to specific projects or programs (MFA 2009h).

In 2009, the total amount of population assistance provided by Finland had increased to EUR 44.5 million (USD 65.5 million - this figure is for comparison purposes and uses the same exchange rate as the one used above in the 2008 survey). Support through multilateral channels totaled EUR 35.1 million, indicating that $78 \%$ of the population assistance provided was directed through multilateral channels - slightly higher than in 2008. Finland's support for IPPF in 2009 (EUR 1 million) was actually paid in 2010 and is therefore not included in these figures. Support for IPPF totaled EUR 800,000 in 2008 and EUR 1 million in both 2009 and 2010, consists of general 
support for IPPF actions and is classified as NGO support. Ipas received programme support totaling EUR 300,000 and Marie Stopes International received EUR 400,000. There is no information available regarding the proportion of population assistance directed through NGOs in 2009 - information regarding NGO assistance is included in the population assistance directed through projects and programs (MFA 2010d and additional information from MFA).

In 2009, taking into consideration the CRS codes not directly related to population activities and using the proportion to which they were estimated to contribute to population activities (e.g. basic education-related actions are estimated to contribute to reproductive health by $10 \%$, basic health activities by $25 \%$, basic nutrition $75 \%$ ) ODA funds provided for population activities through projects or programs totaled EUR 9.4 million (USD 13.9 million). ODA directed to population activities through projects or programs in 2009 was therefore less than in 2008. (Support for IPPF in 2009 (EUR 1 million) would have been included in this figure if it had been actually paid in 2009, but even with the addition, the total level of support would have been smaller than in 2008.) Of this ODA, two-thirds $(67.7 \%)$ went towards basic reproductive health, followed by STD, HIV/AIDS activities (29.1\%), with family planning (2.4\%) and basic research $(0.8 \%)$ being funded to a much lesser extent. The proportions allocated to STD and HIV/AIDS and family planning were higher than in 2008. Support for IPPF would have been classified as support going to reproductive health (MFA 2010d and additional information from MFA).

If only CRS items coded directly for population activities are considered, the amount of ODA committed to population activities through projects or programs in 2009 totaled EUR 5.9 million, of which the basic research category (i.e. CRS 13010 population policy and administrative management) totaled EUR 73,000, the reproductive health category (i.e. CRS 13020 Reproductive health care and CRS 13081 Personnel development for population and reproductive health) totaled EUR 2,865,000, the family-planning category (i.e. CRS 13030) totaled EUR 226,000 and the STD, HIV/ AIDS category (i.e. CRS 13040 STD control, including HIV/AIDS and CRS 16064 Social mitigation of HIV/AIDS) totaled EUR 2,751,000 (MFA 2010d).

The vast majority of ODA with OECD/DAC CRS codes directly related to population activities therefore goes to reproductive health (48.4\%) and STD, HIV/AIDS (46.5\%), while family planning (3.8\%) and basic research (1.2\%) are funded to a significantly lesser extent (MFA 2010d). No information is available on the breakdown of reproductive health between maternal health, abortions, reproductive morbidities and promoting sexual health.

The figures in Table 3 show that the majority of Finland's ODA to SRHR is delivered through multilateral channels. 
Table 3. Summary table: Disbursements through certain channels in 2009 (EUR million).

\begin{tabular}{lc}
\hline Channel & Disbursements, EUR million \\
\hline Health Sector ODA ${ }^{1)}$ & 7.4 \\
Bi-lateral SRHR projects ${ }^{2)}$ & 5.8 \\
UNFPA (core funding only) & 21 \\
SRHR international organizations: UNAIDS & 9 \\
Other SRHR (e.g. innovation, research and & 0.07 \\
development in the SRHR area) ${ }^{3)}$ & 3.5 \\
GFATM & 42.4 \\
European Development Fund & 112.4 \\
Share of EU's development cooperation budget ${ }^{4)}$ & \\
\hline
\end{tabular}

Data: MFA 2010c, 2010d, 2010e, and additional information from MFA Notes:

1) Baskets or funds for joint-financed programs in the health sector: Mozambique EUR 6.0 million, Nicaragua EUR 1.4 million.

2) Based on OECD/DAC CRS codes 13020 (Reproductive health care), 13030 (Family planning), 13040 (STD control including HIVIAIDS), 13081 (Personnel development for population and reproductive health) and 16064 (Social mitigation of HIVIAIDS).

This includes the following bilateral funding: UNFPA EUR 1 million, Ipas EUR 300,000, Marie Stopes International EUR 400,000, among others. NGO ODA on SRHR is also included. (Support totaling EUR 1 million for IPPF would have been added into this figure if it had actually been paid in 2009).

3) Based on OECD/DAC code 13010 (Population policy and administrative management) which is classified as Basic research, data and population and development policy analysis. This also includes health research.

4) Not included in actual development cooperation, but included in the other public development cooperation.

Further study using the same UNFPA/NIDI approach would make it possible to collect slightly more precise figures regarding ODA for SRHR/FP in sub-Saharan Africa than the information presented here. This could be done by collecting DAC-code data concerning only sub-Saharan Africa, and by collecting information concerning NGOs separately. It was not possible to do this for the current report.

\section{Response to specific questions Results of ODA}

The results and influence of Finnish ODA is the subject on an ongoing discussion. The Paris Declaration and the Accra Program of Action guide development work in this field. MFA monitors and evaluates its performance at different levels and is also currently developing its monitoring systems.

ODA projects in reproductive health may target, for example, reductions in levels of maternal mortality. Bilateral programs also usually include built-in indicators which are often quite indicative such as the number of a certain type of training session held. 
There is, however, a need for intermediate measures regarding outcomes, i.e. relationships between the number of training sessions and levels of maternal mortality. This need was clearly recognized by the experts interviewed. Further studies by statistical experts are required.

The Independent Evaluation Unit at MFA is responsible for ODA evaluations, and these are commissioned from independent consultants. Evaluations completed include Cross-cutting issues in Finnish development policy (MFA 2008b), an evaluation of support for development research (MFA 2009d), a meta-analysis on development cooperation connected with HIV/AIDS (MFA 2009e), and meta-analysis of development evaluations in 2007 and 2008 (MFA 2009f), among others.

\section{Support for UNFPA}

In 2009, Finland was UNFPA's eighth-largest supporter in terms of funding. The levels of funding provided by Finland to UNFPA have increased significantly during the 2000s and the strongly-rising trend appears to be continuing: support for UNFPA totaled EUR 21 million in 2009, will be some EUR 25 million in 2010, and is stated to be EUR 28.5 million in 2011 in the Government's budget proposal. This growth has been more significant than that in funds for other UN organizations. In practical terms, funding is delivered as core assistance for UNFPA's budget. Additional thematic support has been provided in some years to the Maternal Health Thematic Fund and to the Global Programme to Enhance Reproductive Health Commodity Security, which promotes safety in reproductive health devices including contraceptives. The latter received EUR 1 million in 2009, the former was not funded in 2009 but received EUR 500,000 in 2008 and earlier years. UNFPA's work has been viewed as concurrent with Finland's policy on sustainable development by supporting curbs on population growth. UNFPA's work also supports measures that improve reproductive health and improvements to the rights and status of women and children, both of which are mentioned in Finnish development policy.

According to MFA, Finland has been satisfied with UNFPA's performance and the reports received. Compared to some other UN organizations, UNFPA appears to be performing well. While there may be a need for improvement in some country offices, the board of the organization is functioning satisfactorily, and UNFPA'a internal monitoring and control system is operating successfully. Finland supports the improvement of efficiency within UNFPA through development of both System-Wide Coherence and the MOPAN system. Finland is also satisfied with its level of influence inside UNFPA, is cooperating with other Nordic countries in UNFPA activities, and has a very good bilateral relationship with the organization. If ideas for further development were to be requested, improvements in results-based management would be useful. In general, the UN and its organizations are highly-respected and trusted in Finland. In its 2010 report, the Development Policy Committee stated that Finland must continue providing long-term core funding to multilateral organizations. 
Other like-minded countries (The Netherlands and Denmark), also strong multilateral supporters of UNFPA, have suggested that UNFPA, which has a strong presence and robust expertise in reproductive health and gender issues in partner countries, could provide support to, among others, the embassies of donor countries in connection with these topics. This could also be useful in implementing a gender dimension within ODA projects. Experts interviewed considered this idea to be worth exploring.

Not all the comments on UNFPA among interviewed representatives of NGOs were entirely positive. The extensive bureaucracy and uneven standard of country offices were subjects for criticism. There is also a need for increased cooperation and discussion between the different international organizations.

\section{Human rights and SRHR}

The Government report on human rights (MFA 2009a) provides a framework which should also be implemented in development cooperation. In this report, the rights of women and girls, including SRHR, were defined as one of the priorities. The current human rights advisor in MFA is linked with ODA activities. The human rights unit participates in planning and shares ideas concerning human rights in ODA. They monitor the situation in partner countries, for example gender issues, and provide guidance on these topics. Gender issues and sexual rights is an area of focus within the unit. Funding is available for locations and projects which would otherwise have no support, but this is provided on a case-by-case basis.

\section{SRHR research funding}

In the main, MFA funds development research through two routes: 1) academic development research administered by the Academy of Finland, funding research projects for maximum of 4 years; and 2) competitive development research, funding shorter commissioned research projects based on tenders. According to one of the experts interviewed, funding of SRHR through these mechanisms has been inadequate. Health - and especially SRHR - has received too little money. In addition, research cooperation is not on the agenda, especially in the fields of health and education. This is different to the situation in Sweden and Norway where research cooperation and capacity building operate at higher levels and have their own financing mechanisms. This point is also in line with the evaluation of support for development research (MFA 2009d), which states that there is an urgent need for accommodating and encouraging cooperative research between Finland and developing countries. For example, field stations concentrating on SRHR could be founded in developing countries. The evaluation of ODA outcomes and impact assessments could also be part of research cooperation. 


\section{Recommendations based on interviews}

Based on material obtained through the interviews conducted for this study, the following recommendations for enhancing ODA directed to SRHR were voiced, among others:

Bilateral health (and SRHR) ODA should be strengthened, and the formulation of a specific SRHR strategy, in addition to having SRHR as a cross-cutting issue, should be considered. The MFA could also be more vocal in the international arena in connection with SRHR, for example in forums associated with the EU and the UN. Training for embassy staff in subjects such as implementing cross-cutting issues or other SRHRrelated training could be requested from UNFPA or IPPF. Intermediate outcome metrics which do not require large amounts of new data to be collected should be developed and it would be good to arrange to have ODA project reports available on the Internet so that the project work is easier to follow. The effectiveness of Finnish investments in SRHR would improve if the research base in this field was stronger. SIDA is an excellent example of this - training opportunities at the Karolinska Institutet have been important for African countries.

Further strengthening the role of NGOs in ODA for FP and SRHR would also be beneficial. The following suggestions were made, among others:

- Expertise in global SRHR issues in Finnish NGOs, such as FFF, could be utilized for example - by providing training in the implementation of cross-cutting issues in projects where they do not easily fit;

- The requirement for NGO self-funding in ODA projects could be removed or reduced through exemptions or other measures;

- NGOs in partner countries could - for example - participate in the collection of information about ODA outcomes in partner countries;

- Some funding or other mechanism for supporting training, lobbying and participation in policy work carried out by Finnish NGOs should be provided, since this is separate from work in the field that is funded by (among other methods) fund raising; and - Improving the consistency of funding of NGO ODA is an important issue. A tax relief system for companies which provide support for foundations would enhance the funding of such organizations and improve ODA funding in the future.

\section{Conclusions and discussion}

The study work reported in this article focused on Finnish ODA directed to FP and SRHR. The primary area of interest was ODA directed towards countries in sub-Saharan Africa, but ODA directed to population activities and SRHR-related activities in other regions was also examined in contexts where making such a precise distinction was not possible. The nature of the information available does not allow a very narrow focus when reporting levels of ODA. Analysis was based on reports, policies and guidelines 
published by the MFA, additional information received from the MFA, and interviews made at the MFA, at the National Institute of Health and Welfare, at the University of Helsinki, at the Parliament, and in relevant NGOs.

In Finland's decision-making structure, the Minister for Foreign Trade and Development who controls the Department of Development Policy at the Ministry for Foreign Affairs (MFA) has, in practice, a lot of autonomy regarding decisions that affect ODA. To date, despite the current economic downturn, levels of ODA have continued to increase in Finland, and are now close to EUR 1 billion. This is the largest budget about which Finnish ministers can make independent decisions. While the degree of activity and level of involvement by different ministers in governing the Department of Development Policy at the MFA has varied, Dr Paavo Väyrynen, Finland's current Minister for Foreign Trade and Development, holds strong views and has been actively involved in decisions made at the ministry. In cases when the minister is less active in terms of participating in the decisions made at different levels in the ministry, civil servants, especially those in the higher ranks, have a greater influence on decisions.

The highest decision-making power, however, belongs to Parliament, which decides on the overall level of ODA funding on the basis of a Government proposal. The general principles and target levels for ODA are decided in a Government programme during the negotiations that take place between political parties before a new coalition government is formed. There are also other stakeholders in the global SRHR sector. The most important advocacy groups or organizations are perhaps the All-Party Parliamentary Group on Population and Development (APPG),The Friday Group, and also, among development NGOs, Väestöliitto, the Family Federation of Finland (FFF), which has an active role in both the APPG and The Friday Group. In the more general field of development policy, important stakeholders include the Service Center for Development Cooperation (KEPA) and the Development Policy Committee, among others. Advocacy groups have been active during the formulation of Development Policy 2007, which is the most important document guiding ODA decisions. Institutions such as The National Institute for Health and Welfare and FFF also make their expertise available to the MFA on demand.

In addition to the Development Policy 2007, other policies, strategies and guidelines guide the making of ODA decisions. The importance of health and SRHR issues in social development is mentioned in Development Policy 2007. Although social development is one of the three components of sustainable development and HIV/AIDS is a cross-cutting issue in development policy, it was the general view of interviewees that the importance of health, SRHR and other 'soft' sectors such as education in Finnish development policy has been declining. On the other hand, the view that population and health issues have never played a very big role in Finnish development policy was also expressed. There were also views (and these were supported by evaluations) 
that cross-cutting issues have not been implemented very well in ODA. According to the MFA, Finland has been satisfied with UNFPA's performance and the reports received and as a major donor, Finland has significant level of influence inside the organization. In recent years multilateral funding for UNFPA, UNAIDS and GFATM has increased and one result has been an increase in the proportion of funding within the health sector that is being directed towards SRHR.

In recent years, the overall level of funding allocated by Finland to ODA has increased, as has the amount of ODA directed to population-related activities (when considering levels in 2008 and 2009). Finnish ODA directed in this manner in 2009 accounted for $4.8 \%$ of total ODA ( $4.9 \%$ if the IPPF funding for 2009 which was paid in 2010 is taken into account). ODA for population activities is almost entirely directed towards basic reproductive health and HIV/AIDS issues. The majority of this funding is directed through multilateral channels (78\% in 2009), the most important of which are UNFPA and UNAIDS, and the funds provided to IPPF represent core funding (i.e. non-earmarked funding) which is not included in the multilateral funding. In the main, these characteristics are in line with recommendations made in the late 1980s (cf. Ritamies 1989), except in connection with the directing of bilateral aid, in which he relative importance of developing family planning services, the collection of demographic information and support for demographic research have all been the subjects of less emphasis than suggested in these early recommendations.

Finland's next parliamentary elections will take place in April 2011. It is highly likely that a new Minister for Foreign Trade and Development will be appointed and that a new Development Policy will be formulated. This will be an important opportunity for advocacy groups whose aim is to promote activity in connection with global population and SRHR issues. In the future, another important topic will probably be the overall level of ODA, and pressure to reduce it because of the economic downturn is almost certain. Important decisions will also be made on which other costs (such as those associated with climate change and the costs of refugees seeking asylum) will be included in ODA. 


\section{List of persons interviewed}

\section{Ministry for Foreign Affairs}

Dr Gisela Blumenthal, Adviser for Health Issues, Department for Development Policy

Ms Päivi Kannisto, Adviser for Gender Issues, Department for Development Policy / Unit for Sector Policies

Mr Marko Laine, Counsellor, Department for Development Policy / Unit for UN Development Affairs

Ms Tanja Leikas-Bottà, Attaché, Unit for Human Rights Policy

Mr Ramses Malaty, Inspector, Department for Development Policy / Unit for General Development Policy and Planning

Ms Heli Mikkola, Adviser for HIV and AIDS, Department for Development Policy

\section{Others}

Dr Marja Anttila, Senior Expert, National Institute for Health and Welfare (THL), International Affairs Unit

Ms Hellevi Hatunen, Head of International Affairs, Family Federation of Finland, Global Development Unit

Dr Elina Hemminki, Research Professor, National Institute for Health and Welfare

Professor Juhani Koponen, Person-in-charge of Development Studies, Department of Political and Economic Studies, University of Helsinki

Ms Niina Pitkänen, Advocacy and Policy Officer, Service Centre for Development Cooperation

Ms Tiina Saarikoski, Health Adviser, Finnish Red Cross, International Operations and Programmes

Ms Minna Sirnö, MP, Chair, the Finnish All-Party Parliamentary Group on Population and Development

Dr Minna Säävälä, Senior Researcher, Family Federation of Finland, Population Research Institute

Ms Mari Tuohimaa, Programme Officer, Eastern Africa, Finnish Red Cross, International Operations and Programmes

Ms Ulla Tervo, Senior Adviser, International Programmes, World Vision Finland Ms Hilkka Vuorenmaa, Senior Advocacy Officer, Family Federation of Finland, Global Development Unit 


\section{References}

Development Policy Committee. 2010. The State of Finland's Development Policy 2010. A Review by the Development Policy Committee for the Finnish Government. Helsinki: Development Policy Committee.

Geisler, Gisela, Berit Austveg, Tone Bleie, Johanne Sundby, Heidi Skramstad, Bawa C. Yamba. Sida's Work Related to Sexual and Reproductive Health and Rights 19942003. Sida Evaluation 04/14. Department for Democracy and Social Development. Stockholm: Swedish International Development Cooperation Agency Sida.

Gould, Jeremy and Lauri Siitonen. 2007. Preface. In: Jeremy Gould and Lauri Siitonen (Eds.): Anomalies of aid: A festschrift for Juhani Koponen. Intercont Books 15. Helsinki: Institute for Development Studies, University of Helsinki, ii-iii.

Gould, Jeremy. 2006. Aid modalities and the arts of government. In: Steen Folke and Henrik Nielsen (Eds.): Aid impact and poverty reduction. Danish Institute for International Studies. New York: Palgrave Mcmillan, 79-94.

Government Statement. 2010. Government Statement to Parliament on the Government Programme of Prime Minister Mari Kiviniemi's Government appointed on 22 June 2010. [cited 15 September 2010]. Available from: $\leq$ http://www.vn.fi/hallitus/ hallitusohjelma/pdf/en.pdf $>$

Hatunen, Hellevi. 1976. Väestöavun politiikka. [Politics of ODA for population activities. In Finnish]. Master's thesis. Department of Social Policy, University of Helsinki.

Hossain, Masud, Lauri Siitonen and Sudhindra Sharma 2006. Development Cooperation for Conflict Prevention and Conflict Resolution: Scope and Potentialities of Finland's Development Co-operation in Nepal. Helsinki: Institute of Development studies, University of Helsinki.

Janssen, Lodevicus J.H. 2009. Management of the Dutch development cooperation. $\mathrm{Ph} . \mathrm{D}$. Thesis, University of Twente, The Netherlands.

KEPA. (Service Center for Development Cooperation). 2010. Kehitystyhteistyö nyt [Development cooperation now. In Finnish]. Raporttisarja 104. Helsinki: Kehitysyhteistyön palvelukeskus Kepa.

Ki-Moon, Ban. 2010. Global strategy for women's and children's health. New York: United Nations.

Kolehmainen-Aitken, Riitta-Liisa, Tom Barton, Hope Chigudu \& Ulrika Edemark. 2005. Finnish Health Sector Development Cooperation 1994-2003. Final Report. Soborg: Euro Health Group.

Konttinen, Tiina. 2007. Learning Challenges of NGOs in Development Cooperation of Finnish NGOs in Morogoro, Tanzania. Helsinki: Helsinki University Press.

Koponen, Juhani. 2004. Development Intervention and Development Studies. In: Tiina Kontinen (Ed.): Development Intervention. Actor and Activity Perspectives. Helsinki: University of Helsinki, 5-13.

Laakso, Liisa. 2007. Politics and partnership in the Cotonou Agreement. In: Jeremy Gould and Lauri Siitonen (Eds.): Anomalies of aid: A festschrift for Juhani Koponen. Intercont Books 15. Helsinki: Institute for Development Studies, University of Helsinki, 116-141. 
Macura, Miroslav, Alphonse L. Mac Donald \& Werner Haug. 2005. The new demographic regime: population challenges and policy responses. United Nations Economic Commission for Europe \& United Nations Population Fund. Geneva: United Nations.

MF (Ministry of Finance). 2010. Valtion talousarvioesitys 2011 [Government's budget proposal to Parliament for 2011. In Finnish]. Helsinki: Ministry of Finance. [cited 19 September 2010]. Available from: $\leq$ http://budjetti.vm.fi/indox/tae/2011/frame 2011.html $>$

MFA (Ministry for Foreign Affairs of Finland). 2010a. General Budget Support and Sector Budget Support in Finland's Programme-based Development Cooperation. Helsinki: Ministry for Foreign Affairs of Finland.

MFA. 2010b. Freedom to choose: Sexual and reproductive health and rights in Finland. Helsinki: Ministry for Foreign Affairs of Finland.

MFA. 2010c. Finland's Development Cooperation 2009. Helsinki: Ministry for Foreign Affairs of Finland. Helsinki: Ministry for Foreign Affairs of Finland.

MFA. 2010d. UNFPA/NIDI Survey on Financial Flows 2009. Report for Finland. Unpublished. Helsinki: Ministry for Foreign Affairs of Finland.

MFA. 2010e. Ohjelmaperusteinen yhteistyö 2000-2009. Raporttisivu. [Program-based ODA, report sheet. In Finnish]. Unpublished. Helsinki: Ministry for Foreign Affairs of Finland.

MFA. 2009a. Government Report to Parliament on the Human Rights Policy of Finland. Publications of the Ministry for Foreign Affairs 14/2009. Helsinki: Ministry for Foreign Affairs of Finland.

MFA. 2009b. The Cross-cutting Themes in Finnish Development Cooperation: Guidelines. Helsinki: Ministry for Foreign Affairs of Finland.

MFA. 2009c. Africa in Finnish development policy - development policy framework programme. Helsinki: Ministry for Foreign Affairs of Finland.

MFA. 2009d. Evaluation: Support to Development Research. Evaluation report 2009:3. Helsinki: Ministry for Foreign Affairs of Finland.

MFA. 2009e. Evaluation: Meta-Analysis on Development Cooperation on HIV/AIDS. Evaluation report 2009:4. Helsinki: Ministry for Foreign Affairs of Finland.

MFA. 2009f. Evaluation: Meta-Analysis on Development Evaluations 2007 and 2008. Evaluation report 2009:9. Helsinki: Ministry for Foreign Affairs of Finland.

MFA. 2009g. Kehitysyhteistyön rahoituskohteet 2009. [Development Cooperation Funding Targets 2009. In Finnish]. Helsinki: Ministry for Foreign Affairs of Finland.

MFA. 2009h. UNFPA/NIDI Survey on Financial Flows 2008. Report for Finland. Unpublished. Helsinki: Ministry for Foreign Affairs of Finland.

MFA. 2009i. Kansalaisjärjestöhankkeet 2009. [NGO projects 2009. In Finnish]. Helsinki: Ministry for Foreign Affairs of Finland.

MFA. 2008a. Multilateral Cooperation in Finland's Development Policy. Helsinki: Ministry for Foreign Affairs of Finland.

MFA. 2008b. Evaluation: The Cross-Cutting Themes in the Finnish Development Cooperation. Evaluation report 2008:6. Helsinki: Ministry for Foreign Affairs of Finland. 
MFA. 2007a. Development Policy Programme 2007: Towards a Sustainable and Just World Community. Government Decision-in-Principle 2007. Helsinki: Ministry for Foreign Affairs of Finland.

MFA. 2007b. Finnish Development Policy Guidelines for the Health Sector. Helsinki: Ministry for Foreign Affairs of Finland.

MFA. 2006. Policy on non-governmental organizations. Helsinki: Ministry for Foreign Affairs of Finland.

MFA 2004. HIV/Aids as a development issue - Foreign Ministry Policy. Helsinki: Ministry for Foreign Affairs of Finland.

Ollila, Eeva. 1994. Suomen kehitysyhteistyön väestöapu. [Finnish population ODA. In Finnish]. In: Eeva Ollila, Päivi Topo, Meri Koivusalo \& Kristiina Kajesalo (Eds.): Vallaton väestö: Kansallisia ja kansainvälisiä väestöpoliittisia kysymyksiä. Porvoo: WSOY. 125-130.

O’Neill, Brian, Landis MacKellar \& Wolfgang Lutz. 2001. Population and climate change. New York: International Institute for Applied Systems Analysis.

Prime Minister's Office. 2007. Government Programme of Prime Minister Matti Vanhanen's second Cabinet. 19 April 2007. [cited 16 June 2010]. Available from: http://www.valtioneuvosto.fi/tietoarkisto/aiemmat-hallitukset/vanhanenII/ hallitusohjelma/pdf/en.pdf

Ritamies, Marketta. 1989. Väestöalan kehitysyhteistyö: Taustaselvitys ja ehdotus Suomen avun suuntalinjoiksi. [ODA for population actions. In Finnish]. Väestöntutkimuslaitos julkaisusarja [Publications of Population Research Institute] D 24. Helsinki: Väestöliitto.

Siitonen, Lauri. 2007. An aid regime at work: European aid and policy export to Nepal and Tanzania. In: Jeremy Gould and Lauri Siitonen (Eds.): Anomalies of aid: A festschrift for Juhani Koponen. Intercont Books 15. Helsinki: Institute for Development Studies, University of Helsinki, 142-167. 